\title{
STUDY OF USE FERMENTED BANANA Musa paradisiaca (Linnaeus, 1761) HUMPS AS ORGANIC FERTILIZER TO IMPROVE NATURAL FEED AVAILABILITY IN NURSERY OF HOVEN'S CARP Leptobarbus hoevenii (Bleeker, 1851) FRY
}

\author{
Wahid Abdul Rosyid*1, Indra Gumay Yudha, dan Herman Yulianto
}

\begin{abstract}
Plankton as a natural feed is thought to be a factor that affects the growth of hoven's carp fry. Plankton abundance can be increased by the addition of organic fertilizers containing nutrients (nitrate and phosphate). Nutrients abundance can be increased by addition of fermented banana hump's This research aimed to determine the use of fermented banana's hump to increase the availability of natural feed nursery and the growth of hoven's carp fry. The method of this research used a completely randomized design with four treatments and three replications, i.e: $P_{1}$ (control), $P_{2}(5,0 \mathrm{ppm}), P_{3}(7,5 \mathrm{ppm})$, and $P_{4}(10,0 \mathrm{ppm})$ addition of fermented banana's hump. The measured parameters were nitrate, phosphate, plankton abundance, growth and water quality. The results showed the dose of addition of banana weed fertilizer had an effect $(P<0.05)$ on the abundance of natural feed and the growth of hoven's carp fry. Results of water quality measurement showed the parameters of temperature ranged from 25 to $27^{\circ} \mathrm{C}, \mathrm{pH}$ ranged from 6,23 to 7,53, DO ranged from 3,40 to 11,36 and ammonia from 0 to $0,001 \mathrm{mg} / \mathrm{l}$. The recomended dosage of fermented banana's hump was $10 \mathrm{ppm}$ for 1 l of water media.
\end{abstract}

Kata kunci: hoven's carp fry., fertilized of banana's hump, natural feed, growth

\section{Pendahuluan}

Ikan jelawat Leptobarbus hoevenii (Bleeker, 1851) merupakan salah satu ikan asli Indonesia yang terdapat di beberapa sungai di Kalimantan dan Sumatera (Kottelat et $a l .$, 1993). Ikan ini banyak ditemui di sungai, anak sungai, dan daerah genangan kawasan hulu hingga hilir, bahkan di muara-muara sungai yang berhutan, sehingga keberadaanya ini masih bergantung pada ketersedianya di alam (Haryono dan Rahardjo, 2009). Meskipun mempunyai nilai ekonomis dan permintaan pasar yang cukup tinggi, namun budidaya ikan jelawat belum dilakukan secara intensif, kendala utama dalam pengembangan budidaya ikan tersebut adalah terbatasnya benih, baik dalam kualitas maupun kuantitasnya (Olivia et al., 2012).

Terbatasnya benih ikan pada fase pendederan ditentukan oleh beberapa faktor, salah satunya

\footnotetext{
${ }^{1}$ E-mail: wahidabdulrosyid@gmail.com

${ }^{2}$ Jurusan Perikanan dan Kelautan, Fakultas Pertanian, Universitas Lampung

Jl. Prof. S. Brodjonegoro No.1 Gedong Meneng Bandar Lampung, 35145
} 
tersedianya pakan alami. Pakan alami yang sangat penting adalah plankton. Plankton tersebut meliputi fitoplankton dan zooplankton. Adapun fitoplankton dan zooplankton dimanfaatkan sebagai sumber makanan dan energi bagi benih ikan yang bersifat omnivora. Plankton tersebut membutuhkan bahan anorganik untuk hidupnya. Bahan anorganik yang dibutuhkan antara lain nitrat dan fosfat dalam bentuk ortofosfat. Bahan anorganik tersebut didapatkan dari pengurain bahan organik oleh mikroba pengurai.

Mikroba pengurai dihasilkan dengan memanfaatkan limbah organik di alam. Salah satunya bonggol pisang yang jarang dimanfaatkan oleh masyarakat. Mikroba yang telah diidentifikasi sebagai mikroba pengurai pada fermentasi bonggol pisang adalah Bacillus sp dan Aspergilus niger (Suhastyo et al., 2013). Mikroba tersebut melakukan proses pemecahan bahan organik menjadi bahan anorganik ( $\mathrm{N}$ dan $\mathrm{P}$ ) yang dibutuhkan oleh fitoplankton untuk pertumbuhan sebagai produsen utama dan sumber pakan zooplankton pada fase pendederan benih ikan jelawat. Oleh karena itu perlu dilakukan penelitian tentang penggunaan bonggol pisang yang difermentasi sebagai pupuk organik untuk meningkatkan ketersediaan pakan alami dan pertumbuhan pada pendederan benih ikan jelawat.

\section{Metode}

Penelitian ini dilaksanakan selama 3 bulan pada Januari-Maret 2018, bertempat di Balai Perikanan Budidaya Air Tawar (BPBAT)
Sungai Gelam, Kabupaten Muaro Jambi, Jambi. Penelitian ini mengunakan rancangan acak lengkap (RAL) dengan 4 perlakuan dan masing-masing perlakuan terdiri dari 3 kali ulangan

Wadah pemeliharaan berupa bak plastik ukuran $74 \times 74 \times 50 \mathrm{~cm}$ sebanyak 12 unit dengan ketinggian air $16 \mathrm{~cm}$ atau sebanyak 501 . Benih yang digunakan berasal dari pemijahan di Balai Perikanan Budidaya Air Tawar Sungai Gelam, meliputi pengukuran panjang dan bobot dari benih. Pengukuran panjang dan bobot tersebut dilakukan secara acak pada $10 \%$ dari jumlah hewan uji setiap bak pendederan. Benih yang digunakan adalah benih yang berumur 7 hari setelah habis kuning telur, dengan padat tebar benih 2 ekor/l.

Parameter yang diuji yaitu kadar nitrat, kadar fosfat, kelimpahan pakan alami meliputi fitoplankton dan zooplankton, pertumbuhan berat dan panjang mutlak. Adapun kualitas air yang diukur meliputi suhu, $\mathrm{pH}, \mathrm{DO}$, dan amonia. Paeameter dianalisis secara statistik dengan menggunakan Anova (Analysis of Variance) dengan selang kepercayaan 95\%. Apabila hasil uji antar perlakuan berbeda nyata maka dilakukan uji lanjut beda nyata terkecil (BNT) dengan tingkat kepercayaan 95\%. Data yang diperoleh dari hasil perhitungan disajikan dalam bentuk tabel dan dianalisis secara deskriptif. Data diolah menggunakan Microsoft Exel 2010 dan Minitab 18. 


\section{Hasil dan Pembahasan}

\section{Kadar Nitrat}

Tabel 1. Rata-rata kadar nitrat (mg/l) media pemeliharaan benih ikan jelawat

\begin{tabular}{cccc}
\hline \multirow{2}{*}{ Perlakuan } & \multicolumn{3}{c}{ Hari ke- } \\
\cline { 2 - 4 } & $\mathbf{0}$ & $\mathbf{7}$ & $\mathbf{1 4}$ \\
\hline \multirow{2}{*}{$\mathrm{P}_{1}$} & $0,097 \pm$ & $0,182 \pm$ & $0,221 \pm$ \\
& $0,066^{\mathrm{a}}$ & $0,060^{\mathrm{c}}$ & $0,206^{\mathrm{b}}$ \\
$\mathrm{P}_{2}$ & $0,098 \pm$ & $0,833 \pm$ & $1,444 \pm$ \\
\multirow{2}{*}{$\mathrm{P}_{3}$} & $0,017^{\mathrm{a}}$ & $0,259^{\mathrm{b}}$ & $1,071^{\mathrm{a}}$ \\
& $0,077 \pm$ & $0,524 \pm$ & $1,515 \pm$ \\
\multirow{2}{*}{$\mathrm{P}_{4}$} & $0,096^{\mathrm{a}}$ & $0,176^{\mathrm{bc}}$ & $0,368^{\mathrm{a}}$ \\
& $0,075 \pm$ & $1,519 \pm$ & $1,924 \pm$ \\
Keterangan: & $0,021^{\mathrm{a}}$ & $0,208^{\mathrm{a}}$ & $0,469^{\mathrm{a}}$ \\
& Notasi yang & berbeda pada kolom \\
& yang sama menunjukkan adanya & perbedaan yang nyata $(\mathrm{P}<0,05)$
\end{tabular}

Hasil penelitian menunjukkan bahwa kadar nitrat pada hari ke-14 pada perlakuan $\mathrm{P}_{2}, \mathrm{P}_{3}$ dan $\mathrm{P}_{4}$ dalam kondisi yang optimum untuk kebutuhan fitoplankton. Hal ini sesuai dengan pernyataan Mackenthun (1969) yang menyatakan bahwa fitoplankton memerlukan kadar optimmum nitrat $0,9-3,5 \mathrm{mg} / \mathrm{l}$. Adapun kadar nitrat pada hari ke-7 menunjukkan kadar nitrat yang optimum untuk kebutuhan fitoplankton hanya pada $\mathrm{P}_{4}$. Tingginya kadar nitrat pada $\mathrm{P}_{2}, \mathrm{P}_{3}$, dan $\mathrm{P}_{4}$ tersebut karena mendapat masukan nutrien hara nitrat dari penambahan pupuk bonggol pisang.

Peningkatan kadar nitrat terjadi karena proses pemberian pupuk bonggol pisang dengan interval 2 hari sekali. Selain dari penambahan pupuk bonggol pisang, peningkatan kadar nitrat merupakan hasil penguraian nitrogen di perairan menjadi amonia melalui proses dekomposisi oleh bakteri pengurai (Bacillus sp) sebagai mikroorganisme lokal yang terkandung dalam pupuk bonggol pisang (Suhastyo, 2013), dengan bantuan oksigen terlarut dalam air, kemudian amonia dioksidasi menjadi nitrit, selanjutnya nitrit dioksidasi menjadi nitrat.

Sedangkan pengamatan kadar nitrat pada $\mathrm{P}_{1}$ hari ke-7 dan hari ke-14 memiliki kandungan nitrat $<0,2 \mathrm{mg} / \mathrm{l}$ yang identik sebagai perairan alami. Kadar nitrat yang rendah pada $\mathrm{P}_{1}$ disebabkan tidak adanya sumber masukan nutrien, sehingga pada $\mathrm{P}_{1}$ terjadi akumulasi kadar amonia pada kisaran $0-0,5 \mathrm{mg} / \mathrm{l}$, lebih tinggi dari kadar amonia $\mathrm{P}_{2}(0-0,002 \mathrm{mg} / \mathrm{l}), \mathrm{P}_{3}$ $(0-0,001 \mathrm{mg} / \mathrm{l})$, dan $\mathrm{P}_{4}(0-0,001$ $\mathrm{mg} / \mathrm{l})$ akibat tidak terjadi proses penguraian amonia oleh bakteri pengurai. Kadar amonia pada $\mathrm{P}_{1}$ lebih tinggi dari rata-rata kadar amonia air kolam, karena menurut Boyd (1991) rata-rata kadar amonia pada air media pendederan sekitar 0,1-0,3 mg/L.

Proses keberadaan nitrat dimedia pendederan benih jelawat didukung oleh beberapa faktor kualitas air, yaitu faktor oksigen terlarut dan suhu. Oksigen terlarut pada media pendederan benih jelawat (DO>3 ppm), masih cukup untuk mendukung proses oksidasi nitrogen. Oksigen terlarut tersebut didukung oleh suhu media pendederan benih jelawat dengan kisaran $24,9-27,3{ }^{\circ} \mathrm{C}$ pada pagi hari dan mengalami kenaikan pada siang hari.

Berdasarkan uji statistik pada tingkat kepercayaan 95\% menunjukkan bahwa pemberian dosis pupuk bonggol pisang berpengaruh nyata terhadap kadar nitrat pada hari ke-7 dan hari ke-14. Hal ini menunjukkan bahwa penambahan pupuk bonggol pisang yang mengandung unsur hara nitrat sebesar 
3.087 ppm dapat meningkatkan kadar nitrat pada media pendederan benih jelawat.

Hal ini sesuai dengan Suhastyo (2013), yang menyatakan bahwa Bacillus sp termasuk spesies yang hidup bebas yang mempunyai kemampuan merombak senyawa organik, dan berperan seperti dalam proses nitrifikasi dan denitrifikasi. Poxton (1991) dalam Midlen \&
Redding (2000) menyatakan nitrat merupakan produk akhir dari proses nitrifikasi, tidak bersifat toksik bagi ikan kecuali pada konsentrasi yang sangat tinggi (>100 mg/l).

\section{Kadar Ortofosfat}

Effendi (2003) menyatakan perairan dengan tingkat kesuburan sedang dengan kadar ortofosfat antara $0,021-0,5 \mathrm{mg} / \mathrm{l}$. (Tabel 2).

Tabel 2. Rata-rata kadar orthofosfat (mg/l) media pendederan benih ikan jelawat

\begin{tabular}{cccc}
\hline \multirow{2}{*}{ Perlakuan } & \multicolumn{3}{c}{ Hari ke- } \\
\cline { 2 - 4 } & $\mathbf{0}$ & $\mathbf{7}$ & $\mathbf{1 4}$ \\
\hline $\mathrm{P}_{1}$ & $0,0009 \pm 0,0001^{\mathrm{a}}$ & $0,0009 \pm 0,0004^{\mathrm{b}}$ & $0,0000 \pm 0,0000^{\mathrm{b}}$ \\
$\mathrm{P}_{2}$ & $0,0013 \pm 0,0008^{\mathrm{a}}$ & $0,0190 \pm 0,0074^{\mathrm{a}}$ & $0,0167 \pm 0,0030^{\mathrm{a}}$ \\
$\mathrm{P}_{3}$ & $0,0009 \pm 0,0006^{\mathrm{a}}$ & $0,0229 \pm 0,0059^{\mathrm{a}}$ & $0,0200 \pm 0,0066^{\mathrm{a}}$ \\
$\mathrm{P}_{4}$ & $0,0003 \pm 0,0001^{\mathrm{a}}$ & $0,0256 \pm 0,0040^{\mathrm{a}}$ & $0,0371 \pm 0,0236^{\mathrm{a}}$ \\
\hline
\end{tabular}

Keterangan: Notasi yang berbeda pada kolom yang sama menunjukkan adanya perbedaan yang nyata $(\mathrm{P}<0,05)$

Hasil penelitian menunjukkan bahwa kadar ortofosfat pada perlakuan $\mathrm{P}_{2}, \mathrm{P}_{3}$, dan $\mathrm{P}_{4}$ dalam kondisi dibawah kadar optimum yang diperlukan fitoplankton, Mackentum (1969), menyatakan kadar ortofosfat yang optimum $0,09-1,80 \mathrm{mg} / \mathrm{l}$. Namun berdasarkan klasifikasi kadar fosfat digolongkan sebagai perairan dengan tingkat kesuburan sedang, karena mengandung kadar ortofosfat antara $0,021-0,5 \mathrm{mg} / \mathrm{l}$ (Effendi, 2003). Tinggi rendahnya kadar ortofosfat pada perlakuan $\mathrm{P}_{2}, \mathrm{P}_{3}$, dan $\mathrm{P}_{4}$ karena mendapat masukan nutrien hara fosfat dari penambahan pupuk bonggol pisang. Peningkatan kadar orthofosfat terjadi karena proses pemberian pupuk bonggol pisang dengan interval 2 hari sekali. Selain dari penambahan pupuk bonggol pisang, peningkatan kadar ortofosfat diduga merupakan hasil ionisasi fosfat yang berasal dari feses, sisa tulang benih yang mati, dan dari jaringan tumbuhan air dan benih yang sudah mati menjadi ortofosfat dalam media pendederan benih jelawat.

Sedangkan pengamatan kadar orthofosfat pada $\mathrm{P}_{1}$ hari ke-7 dan hari ke-14 memiliki kadar ortofosfat $<0,02 \mathrm{mg} / \mathrm{l}$, diklasifikasikan sebagai perairan dengan tingkat kesuburan rendah (Effendi, 2003). Kadar ortofosfat yang rendah pada $\mathrm{P}_{1}$ karena tidak ada masukan nutrien fosfat. Proses ionisasi ortofosfat dimedia pendederan benih jelawat didukung oleh beberapa faktor kualitas air, yaitu faktor oksigen terlarut dan suhu. Oksigen terlarut diperairan yang membantu proses ionisasi fosfat dari sisa feses dan jaringan tumbuhan dan hewan yang mati. Oksigen terlarut pada media pendederan benih jelawat (>3 ppm), masih cukup untuk mendukung proses ionisasi fosfor. Oksigen terlarut tersebut didukung oleh suhu media pendederan benih jelawat dengan kisaran $24,9-27,3^{\circ} \mathrm{C}$ 
pada pagi hari dan mengalami kenaikan pada siang hari.

Berdasarkan uji statistik pada tingkat kepercayaan $95 \%$ menunjukkan bahwa pemberian dosis pupuk bonggol pisang berpengaruh nyata terhadap kadar ortofosfat pada hari ke-7 dan hari ke-14. Hal ini menunjukkan bahwa penambahan pupuk organik yang mengandung fosfat 439 ppm dari bonggol pisang yang difermentasi dan mengandung mikroba Bacillus sp dan Aspergilus niger dapat meningkatkan kadar ortofosfat pada media pendederan benih jelawat.

\section{Kelimpahan Fitoplankton}

Fitoplankton

yang

teridentifikasi adalah Ulotrix sp dan Coelastrum sp dari filum Chlorophyta dari kelas Chlorophyceae. Sebagaimana kebanyakan Chlorophyta bersifat autotrof yang dapat memanfaatkan bahan anorganik dengan bantuan energi matahari dan energi kimia, sehingga Chlorophyta banyak ditemukan di perairan dengan kandungan nitrat yang tinggi. Hal tersebut sesuai dengan kondisi kualitas air di media pemeliharaan, dengan kadar nitrat dan ortofosfat yang lebih tinggi dibandingkan dengan nutrien yang lain.

Dari kedua jenis fitoplankton tersebut, diduga keduanya dimakan secara langsung oleh benih jelawat. Menurut Niken (2011) Coelastrum sp. teridentifikasi dalam usus benih ikan nilem dari famili yang sama dengan ikan jelawat yaitu cyprinidae yang berumur 17 hari setelah menetas. Selanjutnya (Andrea et al., 2013) menyebutkan Ulotrix sp teridentifikasi dalam usus benih ikan Pseudoplatystoma sp dengan rata-rata berat 0,0958 $\mathrm{g}$ (Tabel 3).

Tabel 3. Rata-rata kelimpahan fitoplankton (ind/l) media pendederan ikan jelawat.

\begin{tabular}{cccc}
\hline \multirow{2}{*}{ Perlakuan } & \multicolumn{3}{c}{ Hari ke- } \\
\cline { 2 - 4 } & $\mathbf{0}$ & $\mathbf{7}$ & $\mathbf{1 4}$ \\
\hline $\mathrm{P}_{1}$ & $1.500 \pm 750^{\mathrm{a}}$ & $3.750 \pm 1.500^{\mathrm{c}}$ & $13.833 \pm 1.774^{\mathrm{c}}$ \\
$\mathrm{P}_{2}$ & $2.250 \pm 750^{\mathrm{a}}$ & $21.000 \pm 2.250^{\mathrm{b}}$ & $34.800 \pm 5.086^{\mathrm{b}}$ \\
$\mathrm{P}_{3}$ & $750 \pm 750^{\mathrm{a}}$ & $23.250 \pm 2250^{\mathrm{b}}$ & $46.617 \pm 11.665^{\mathrm{b}}$ \\
$\mathrm{P}_{4}$ & $2.250 \pm 750^{\mathrm{a}}$ & $29.250 \pm 1.500^{\mathrm{a}}$ & $76.500 \pm 11.000^{\mathrm{a}}$ \\
\hline
\end{tabular}

Keterangan: Notasi yang berbeda pada kolom yang sama menunjukkan adanya perbedaan yang nyata $(\mathrm{P}<0,05)$

Berdasarkan kategori kelimpahan fitoplankton, penelitian ini termasuk dalam kategori sedang dengan jumlah individu antara $10^{3}-$ 10\% (Majidek, 2016). Fitoplankton tersebut dimanfaatkan benih ikan jelawat sebagai makanan, sesuai ekologi benih jelawat yang berumur 5 -25 hari bersifat omnivora, setelah 25 hari benih jelawat akan cenderung herbifora (Termvidchakorn et al., 2013). Pemilihan plankton sebagai makanan benih ikan jelawat berkaitan dengan cara makan benih ikan jelawat yang pada umur tersebut letak mulut benih jelawat adalah superior, dengan demikian benih ikan jelawat termasuk kedalam ikan yang memiliki cara makan dengan tipe menyambar makanan yang melayang, namun demikian benih jelawat mengambil makanan dengan cara menghisap yang berada di dasar perairan (Baskoro, 2007). 
Berdasarkan uji statistik pada tingkat kepercayaan 95\% menunjukkan bahwa pemberian dosis pupuk bonggol pisang berpengaruh nyata terhadap kelimpahan fitoplankton media pendederan pada hari ke-7 dan hari ke-14.

Tinggi rendahnya kelimpahan fitoplankton dipengaruhi oleh kadar nitrat dan orthofosfat yang dimanfaatkan secara langsung oleh plankton media pendederan benih jelawat. Analisis statistik dalam menentukan korelasi antara kelimpahan fitoplankton dan kandungan nitrat dan fosfat dilakukan dengan menggunakan analisis regresi linear berganda pada Microsoft Excel. (Tabel 4).

Tabel 4. Hasil analisis korelasi regresi ganda kelimpahan fitoplankton dengan kimia air $\left(\mathrm{X}_{1}\right.$ : Nitrat; $\mathrm{X}_{2}$ : Ortofosfat $)$

\begin{tabular}{cccc}
\hline Perlakuan & Persamaan Regresi Ganda & $\mathbf{R}$ & $\mathbf{R}^{\mathbf{2}}$ \\
\hline $\mathrm{P}_{1}$ & $\mathrm{Y}=14.412-629 \mathrm{X}_{1}-10.969 .261 \mathrm{X}_{2}$ & 0,60 & 0,70 \\
$\mathrm{P}_{2}$ & $\mathrm{Y}=5.305+4.007 \mathrm{X}_{1}+461.941 \mathrm{X}_{2}$ & 0,68 & 0,76 \\
$\mathrm{P}_{3}$ & $\mathrm{Y}=7.770+45.678 \mathrm{X}_{1}-537.443 \mathrm{X}_{2}$ & 0,70 & 0,77 \\
$\mathrm{P}_{4}$ & $\mathrm{Y}=7.770+45.678 \mathrm{X}_{1}-537.443 \mathrm{X}_{2}$ & 0,51 & 0,63 \\
\hline
\end{tabular}

Hasil analisis regresi berganda terhadap kelimpahan fitoplankton (Y) dipengaruhi oleh nitrat $\left(\mathrm{X}_{1}\right)$ dan fosfat $\left(\mathrm{X}_{2}\right)$ pada $\mathrm{P}_{1}$ menunjukkan nilai koefisien korelasi (r) sebesar 0,60 yang berarti memiliki hubungan yang kuat, pada $\mathrm{P}_{2}$ menunjukkan nilai koefisien korelasi (r) sebesar 0,68 yang berarti memiliki hubungan yang kuat, pada $\mathrm{P}_{3}$ menunjukkan nilai koefisien korelasi (r) sebesar 0,70 yang berarti memiliki hubungan yang kuat, pada $\mathrm{P}_{4}$ menunjukkan nilai koefisien korelasi (r) sebesar 0,51 yang berarti memiliki hubungan yang sedang. Adapun hubungan antara interval koefisien dan tingkat hubungan yaitu 0,00-0,1999 (sangat rendah), 0,20 - 0,399 (rendah), 0,40 0,59 (sedang), 0,60 - 0,79 (kuat), 0,80 - 1 (sangat kuat) (Supranto, 2009).

\section{Kelimpahan Zooplanktom}

Steeman-Nielsen (1971), menyatakan bahwa pertumbuhan zooplankton lebih lambat dari fitoplankton, maka populasi maksimum zooplankton akan tercapai beberapa waktu setelah populasi maksimum fitoplankton berlalu. Zooplankton yang yang teridentifikasi dalam penelitian ini Brachionus sp. (Tabel 5).

Tabel 5. Rata-rata kelimpahan Brachionus sp (ind/) media pendederan benih ikan jelawat

\begin{tabular}{ccc}
\hline \multirow{2}{*}{ Perlakuan } & \multicolumn{2}{c}{ Hari ke- } \\
\cline { 2 - 3 } & $\mathbf{7}$ & $\mathbf{1 4}$ \\
\hline $\mathrm{P}_{1}$ & $750 \pm 250^{\mathrm{b}}$ & $417 \pm 382^{\mathrm{c}}$ \\
$\mathrm{P}_{2}$ & $1.250 \pm 433^{\mathrm{a}}$ & $1.000 \pm 0^{\mathrm{b}}$ \\
$\mathrm{P}_{3}$ & $1.250 \pm 433^{\mathrm{a}}$ & $1.167 \pm 382^{\mathrm{ab}}$ \\
$\mathrm{P}_{4}$ & $2.083 \pm 381^{\mathrm{a}}$ & $1.583 \pm 144^{\mathrm{a}}$ \\
\hline
\end{tabular}

Keterangan: Notasi yang berbeda pada kolom yang sama menunjukkan adanya perbedaan yang nyata $(\mathrm{P}<0,05)$

Brachionus sp merupakan zooplankton dari filum Rotifera. Menurut Isnantyo \& Kurniastuty (1995), Rotifera termasuk kedalam pakan alami yang baik di dalam budidaya karena mudah dilihat oleh benih ikan, gerakan yang lambat serta mempunyai daya apung yang baik, namun karena dalam pendederan ini 
menggunakan benih jelawat dari umur $7-21$ hari ketika sifat makannya omnivora, sehingga benih jelawat pada penelitian ini tidak hanya memangsa plankton ini. Berdasarkan kategori kelimpahan zooplankton, pada $\mathrm{P}_{2}, \mathrm{P}_{3}$, dan $\mathrm{P}_{4}$ kelimpahan zooplankton pada pengamatan hari ke-7 dan ke-14 dikategorikan tinggi. Majidek (2016) menyatakan zooplankton dikategorikan rendah dengan jumlah individu kurang dari $50 \mathrm{ind} / 1$, sedang dengan jumlah individu antara $50-500$ ind/l, dan dikategorikan tinggi dengan jumlah individu lebih dari $500 \mathrm{ind} / 1$.

Berdasarkan uji statistik pada tingkat kepercayaan 95\% menunjukkan bahwa pemberian dosis pupuk bonggol pisang berpengaruh nyata terhadap kelimpahan zooplankton media pendederan pada hari ke-7 dan hari ke-14. Hal ini menunjukkan bahwa penambahan pupuk dari bonggol pisang yang difermentasi dengan tiga dosis berbeda dapat meningkatkan kelimpahan zooplankton sesuai dengan tingkat kelimpahan fitoplankton yang dimanfaatkan sebagai sumber makanannya pada pendederan benih ikan jelawat.

Perbedaan kelimpahan zooplankton berkaitan dengan nilai kadar nitrat dan ortofosfat di media pendederan, semakin tinggi nilai kadar nitrat dan ortofosfat. Nitrat dan ortofosfat berkaitan dengan Brachionus sp Sebab nitrat di perairan merupakan sumber utama sebagai nutrien bagi pertumbuhan plankton dan alga (Effendi, 2003). Adapun ortofosfat merupakan senyawa fosfor terkecil, di perairan orthofospat di gunakan untuk transfer energi dalam aktivitas fotosintesis fitoplankton (Harris, 1978 dalam Suprapto et al., 2014).

\section{Pertumbuhan Benih Jelawat}

Pertumbuhan merupakan perubahan bentuk ikan baik panjang maupun berat sesuai dengan perubahan waktu (Effendi, 1979).

Tabel 6. Rata-rata pertumbuhan panjang mutlak ( $\mathrm{mm})$ dan berat mutlak (gram) benih ikan jelawat

\begin{tabular}{ccccc}
\hline \multirow{2}{*}{ Perlakuan } & \multicolumn{2}{c}{ Rata-rata panjang hari ke- } & \multicolumn{2}{c}{ Rata-rata berat hari ke- } \\
\cline { 2 - 5 } & $\mathbf{7}$ & $\mathbf{1 4}$ & $\mathbf{7}$ & $\mathbf{1 4}$ \\
\hline $\mathrm{P}_{1}$ & $0,79 \pm 0,69^{\mathrm{b}}$ & $2,75 \pm 0,28^{\mathrm{c}}$ & $0,049 \pm 0,005^{\mathrm{b}}$ & $0,120 \pm 0,004^{\mathrm{c}}$ \\
$\mathrm{P}_{2}$ & $2,48 \pm 0,72^{\mathrm{a}}$ & $4,63 \pm 0,79^{\mathrm{b}}$ & $0,088 \pm 0,002^{\mathrm{a}}$ & $0,204 \pm 0,008^{\mathrm{b}}$ \\
$\mathrm{P}_{3}$ & $2,61 \pm 0,97^{\mathrm{a}}$ & $5,21 \pm 0,80^{\mathrm{ab}}$ & $0,088 \pm 0,001^{\mathrm{a}}$ & $0,216 \pm 0,009^{\mathrm{b}}$ \\
$\mathrm{P}_{4}$ & $3,45 \pm 1,07^{\mathrm{a}}$ & $6,40 \pm 0,92^{\mathrm{a}}$ & $0,092 \pm 0,003^{\mathrm{a}}$ & $0,243 \pm 0,002^{\mathrm{a}}$ \\
\hline
\end{tabular}

Keterangan: Notasi yang berbeda pada kolom yang sama menunjukkan adanya perbedaan yang nyata $(\mathrm{P}<0,05)$

Rata rata pertumbuhan panjang benih ikan jelawat di akhir penelitian ketika umur 21 hari masih tergolong lambat dibandingkan dengan rata-rata pertumbuhan panjang benih ikan jelawat pada penelitian Termvidchakorn et al. (2013) yang menyebutkan angka pertumbuhan panjang benih ikan jelawat pada umur 21 hari mencapai panjang 22,6 $\mathrm{mm}$. Putra et al. (2008), menyatakan salah satu sebab yang mempengaruhi kecepatan pertumbuhan benih ikan adalah jenis dan jumlah makanan yang dimakan benih ikan. Minimnya sumber makanan alami baik jumlah 
maupun jenis dimedia pendederan baik dari diduga menyebabkan lambatnya pertumbuhan benih jelawat, karena dalam penelitian ini benih jelawat masa pendederan usia 7-21 hari bersifat omnivora (Termvidchakorn et al., 2013).

Berdasarkan uji statistik pada tingkat kepercayaan $95 \%$ menunjukkan bahwa pemberian dosis pupuk bonggol pisang berpengaruh nyata terhadap pertumbuhan panjang dan berat mutlak benih ikan jelawat media pendederan pada hari ke-7 dan hari ke-14 menunjukkan perbedaan sangat nyata dengan tiga perlakuan penambahan pupuk bonggol pisang dengan dosis berbeda.

Hal ini menunjukkan bahwa semakin tinggi dosis pupuk bonggol pisang yang diberikan pada $\mathrm{P}_{2}, \mathrm{P}_{3}$, dan $\mathrm{P}_{4}$ di media pendederan benih jelawat, pertumbuhan panjang dan berat mutlak juga semakin tinggi. Hal tersebut karena kadar nitrat dan ortofosfat dalam pupuk bonggol pisang yang dimanfaatkan untuk aktivitas fotosintesis fitoplankton semakin tinggi (Harris, 1978 dalam Suprapto et al., 2014). Adapun jumlah fitoplankton pada $\mathrm{P}_{4}$ yang dimanfaatkan baik secara langsung oleh benih jelawat, maupun melalui proses pemangsaan oleh zooplankton sebagai makanan benih jelawat semakin tinggi.

Karena sumber energi dari makanan yang dimanfaatkan benih ikan jelawat baik dari fitoplankton maupun zooplankton, awalnya digunakan untuk memelihara tubuh dan menggantikan sistem jaringan tubuh yang rusak, selanjutnya kelebihan energi yang digunakan akan dimanfaatkan untuk pertumbuhan (Asmawi, 1983).

Hal ini sesuai dengan pernyataan Huet (1986) yang menyatakan bahwa pertumbuhan ikan terjadi karena tersedianya pakan dalam jumlah yang cukup, dimana pakan yang dikonsumsi lebih besar dari kebutuhan pokok untuk kelangsungan hidup. Menurut (Lovell, 1988) pertambahan berat tubuh benih ikan menunjukkan bahwa energi dalam pakan yang dikonsumsi benih ikan melebihi kebutuhan energi untuk pemeliharaan tubuh.

\section{Parameter fisika-kimia pendukung}

Hasil pengukuran kualitas air sebagai data pendukung untuk mengetahui variasi parameter pada perlakuan penambahan pupuk bonggol pisang (Tabel 7).

Tabel 7. Nilai parameter fisika-kimia media pemeliharan benih ikan jelawat yang diberi penambahan pupuk bonggol pisang

\begin{tabular}{|c|c|c|c|c|c|c|}
\hline \multirow{2}{*}{ Parameter } & \multirow{2}{*}{ Satuan } & \multicolumn{4}{|c|}{ Rentang Nilai } & \multirow{2}{*}{ Kadar Optimum } \\
\hline & & $\mathbf{P}_{1}$ & $\mathbf{P}_{2}$ & $\mathbf{P}_{3}$ & $\mathbf{P}_{4}$ & \\
\hline \multicolumn{7}{|c|}{ Fisika } \\
\hline Suhu & $\left({ }^{\circ} \mathrm{C}\right)$ & $24,9-27,2$ & $24,9-27,2$ & $24,9-27,2$ & $25,0-27,3$ & $23-31 *$ \\
\hline Kecerahan & $(\mathrm{cm})$ & 16 & 16 & 16 & 16 & - \\
\hline \multicolumn{7}{|c|}{ Kimia } \\
\hline $\mathrm{pH}$ & & $6,07-7,69$ & $6,28-7,45$ & $6,53-7,45$ & $6,23-7,53$ & $6-7,9 *$ \\
\hline DO & (ppm) & $4,02-10.0$ & $4,02-11,09$ & $3,47-9,66$ & $3,40-11,36$ & $>3 *$ \\
\hline Amonia & $(\mathrm{mg} / \mathrm{l})$ & $0-0,5$ & $0-0,005$ & $0-0,001$ & $0-0,001$ & $0,1-0,3 * *$ \\
\hline
\end{tabular}

Keterangan:* Baskoro (2007)

**Boyd (1991) 
Parameter kualitas air menjadi standar terhadap kehidupan organisme budidaya. Kualitas air tidak hanya dipengaruhi oleh keadaan ekosistem budidaya, namun juga dipengaruhi oleh kandungan nutrien. Menurut Febrianty (2011), nutrien yang masuk ke perairan dapat mempengaruhi kualitas air di perairan tersebut.

Suhu pada semua perlakuan penambahan pupuk bonggol pisang berada pada kisaran toleransi yang dibutuhkan oleh benih ikan jelawat sebab menurut Baskoro (2007) suhu yang paling baik untuk hidup pada fase pertumbuhan ikan jelawat pada kisaran $23-31^{\circ} \mathrm{C}$. Tingginya oksigen terlarut pada media pemeliharaan benih jelawat disebabkan kisaran suhu yang rendah (Baskoro, 2007).

Kecerahan pada media pemeliharaan dengan perlakuan penambahan pupuk bonggol pisang berada tergolong tinggi, karena pemeliharaan dilakukan di luar ruangan sehingga intensitas cahaya matahari mampu menembus dasar media pemeliharaan. Intensitas cahaya matahari yang menyebar di semua media pemeliharaan menyebabkan produktivitas fitoplankton maksimal dan mempunyai pengaruh terbesar, yaitu sebagai sumber energi untuk proses fotosintesis tumbuh tumbuhan yang menjadi makanan benih jelawat (Juwana \& Romimohtarto, 2001)

Nilai pH air pada media pendederan perlakuan penambahan pupuk bonggol pisang berada pada nilai yang dibutuhkan oleh benih ikan jelawat untuk kehidupannya yaitu pada kisaran 6 - 7,9 (Baskoro, 2007). Sehingga kisaran nilai $\mathrm{pH}$ pada media pendederan mendukung kehidupan benih jelawat. Odum \& Barrett (1971) menyatakan perairan dengan $\mathrm{pH}$ antara $6-9$ merupakan perairan dengan kesuburan yang tinggi dan tergolong produktif karena memiliki kisaran $\mathrm{pH}$ yang dapat mendorong proses pembongkaran bahan organik yang ada dalam perairan menjadi bahan organik yang lebih komplek yang dapat diasimilasikan oleh fitoplankton.

Oksigen terlarut (DO) di media pemeliharaan perlakuan penambahan pupuk bonggol pisang berada pada nilai $\mathrm{DO}>3 \mathrm{ppm}$, tergolong baik karena memiliki kadar sesuai yang dibutuhkan untuk kehidupan ikan jelawat (Baskoro, 2007). Kisaran oksigen terlarut yang tinggi diduga disebabkan oleh suhu yang rendah pada saat pengamatan yang dilakukan pada pukul 07:30 pada saat suhu relatif rendah.

\section{Kesimpulan dan Saran}

Dosis pupuk organik dari fermentasi bonggol pisang yang optimal untuk meningkatkan ketersediaan pakan alami dan meningkatkan pertumbuhan benih ikan jelawat adalah $10 \mathrm{ppm}$ dalam liter air media. Adapun saran bagi pembudidaya, pupuk bonggol pisang dapat digunakan sebagai alternatif dalam proses budidaya karena dapat menghemat biaya pakan pada fase pendederan.

\section{Daftar Pustaka}

Andrea, F.L.D., Marcia, R.R., Lucimara, A.R., \& Aryadne, S.R. 2013. Feeding of Larvae of the Hybrid Surubim (Pseudoplatystoma sp). Under 
Two Conditions of Food Management. Acta Scientiarum. Biological Sciences, 35(2): 149 155.

Asmawi, S. 1983. Pemeliharaan Ikan dalam Keramba. Gramedia, Jakarta. $82 \mathrm{hlm}$.

Baskoro. 2007. Pelatihan Pengelolaan dan Pembenihan Ikan Jelawat (Leptobarbus hoevenii). Balai Budidaya Air Tawar Mandiangin, Direktorat Jendral Perikanan Budidaya, Departemen Kelautan dan Perikanan, Mandiangin. $15 \mathrm{hlm}$.

Boyd, C.E. 1991. Water Quality Managementand Aeration in Srimp Farming. Water Harvesting Project of Auburn University, Amsterdam. $70 \mathrm{hlm}$.

Effendi, M.I. 1979. Metode Biologi Perikanan. Yayasan Dewi Sri, Bogor. 112 hlm.

Effendi, M.I. 2003. Telaah Kualitas Air. Kanisius, Yogyakarta. 111 hlm.

Febrianty, E. 2011, Produktivitas Alga (Hydrodictyon) pada Sistem Perairan Tertutup (Closed System). Skripsi. Institut Pertanian Bogor, Bogor. 58 hlm

Haryono \& Rahardjo, M.F. 2009. Pertumbuhan Anakan Ikan Jelawat Hasil Reproduksi Buatan (Bagian VI) dalam Proses Domestikasi dan Reproduksi Ikan Jelawat yang Telah Langka Menuju Budidayanya. Lembaga Ilmu Pengetahuan Indonesia, Bogor. $81 \mathrm{hlm}$.

Huet, M. 1986. Text Book of Fish Culture Breeding and Cultivation of Fish. Fishing New (Book) Ltd., Oxford. $328 \mathrm{Hlm}$.

Isnansetyo, A., \& Kumiastuty, E. 1995. Teknik Kultur
Phytoplankton Dan Zooplankton.

Pakan Alami Untuk Pembenihan

Organisme Laut. Penerbit

Kanisius, Yogyakarta. $116 \mathrm{hlm}$.

Juwana, S. \& Romimohtarto, K. 2001. Biologi Laut: Ilmu Pengetahuan Tentang Biota Laut. Puslitbang Oseanologi LIPI, Jakarta. 527 hlm.

Kottelat, M., Whitten, A.J., Kartikasari, S .N., \& Wirjoatmodjo, S. 1993. Freshwater Fishes of Western Indonesia and Sulawesi. Periplus Edition, Hongkong. $124 \mathrm{hlm}$.

Lovell, R.T. 1988. Nutrition and Feding of Fish. An AVI Book, van Nonstrad Reinhold, New York. $269 \mathrm{Hlm}$.

Mackenthun, K.M. 1969. The Practice of Water Pollution Biology. Departement of Interior, Federal Water Pollution Control Administration, Washington. 285 hlm.

Majidek, A. 2016. Pengamatan Kelimpahan Plankton di Perairan BPBL Batam. Laporan Magang. Universitas Maritim Raja Ali Haji, Tanjungpinang. $33 \mathrm{hlm}$.

Niken, T.M.P., Winarlim, Yuki, H.E.F., \& Aliati, I. 2011. Potensi Plankton sebagai Pakan Alami Larva Ikan Nilem (Osteochilus hasselti C.V). Jurnal Akuakultur Indonesia, 10(1): $81-88$.

Odum, E.P. \& Barrett, G.W. 1971. Fundamentals of Ecology, $3^{\text {rd }}$ ED. W.B. Saunders Company, Philadelphia. 564 hlm.

Olivia, S., Huwoyon, G.H., \& Prakoso, V.A. 2012. Perkembangan Embrio dan Sintasan Larva Ikan Jelawat (Lebtobarbus hoevanii) pada Berbagai Suhu Air. Bulletin Litbang: 135 - 144. 
Putra. R.M., Pulungan, C.P., Windarti, \& Efizon, D. 2012. Buku Ajar Biologi Perikanan. Unri Press, Pekanbaru. 50 hlm.

Suhastyo, A.A. 2013. Studi Mikrobiologi dan Sifat Kimia Mikroorganisme Lokal. Saintek, 10(2): $29-39$.

Supranto, J. 2009. Statistik Teori dan Aplikasi. Erlangga, Jakarta. 384 hlm.

Suprapto, D., Purnomo, P.W., \& Sulardiono, B. 2014. Analisis Kesuburan Perairan Berdasarkan Hubungan Fisika Kimia Sedimen Dasar dengan $\mathrm{NO}_{3}{ }^{-} \mathrm{N}$ dan $\mathrm{PO}_{4}{ }^{-} \mathrm{P}$ di Muara Sungai Tuntang Demak. Saintek Perikanan, 10(1): 56 - 61. Steeman-Nielsen, E. 1971. Marine Photosinthesis with Emphasis on the Ecological Aspect. Elseiver Science, 13(1): 1 - 141.

Termvidchakorn, A. \& Hortle, K.G. 2013. A Guide to Larvae and Juveniles of Some Common Fish Species from the Mekong River Basin. MRC Technical Paper no. 38 Mekong River Commision, Phnom Penh. 234 hlm.

Wardoyo. S.E., \& Yusuf, T.B. 1999. Perlakuan Terhadap Media dalam Budidaya Ikan Sistem Tertutup. Puslitbang Perikanan, 3(1): 1 - 9. 
